\title{
English Teaching Methodologies of Modern Languages Graduates from a University in Colombia
}

\author{
Metodologías en la enseñanza del inglés de egresados de lenguas \\ modernas de una universidad en Colombia
}

\section{Carmelina Encarnación Mosquera ${ }^{1}$}

\begin{abstract}
Self-assessment for accreditation purposes requires follow-up of graduates and feedback with academic programs. As part of the improvement actions, this study was done to characterize graduates' methodologies in English language teaching. The data, gathered through questionnaires, showed that graduates privilege the communicative and eclectic methods; the criteria for selecting methodologies are based on their relevance in the teaching context and students' learning needs; furthermore, there is a need and expectation to be updated in methodologies according to the guidelines of the National Bilingual Program. It would be relevant that these results were considered in the curricular development of modern languages and in graduates' professional development activities.

Keywords: approach, method, methodology, teaching strategies

\section{Resumen}

La autoevaluación con fines de acreditación requiere del seguimiento a egresados y la retroalimentación con programas académicos. Como parte de las acciones de mejoramiento, se emprendió este estudio con el fin de caracterizar las metodologías de egresados en la enseñanza del inglés. Los datos recolectados por medio del uso de cuestionarios mostraron que los egresados privilegian el método comunicativo y el ecléctico; los criterios para seleccionar las metodologías se basan en su pertinencia en el contexto de enseñanza y las necesidades de aprendizaje de los estudiantes; existe la necesidad y
\end{abstract}

She is an associate teacher at the University of Cauca. She works at the Languages Department. She graduated from a Master's in English Didactics at Universidad de Caldas in 2010. She has been a teacher trainer in Cauca department for more than five years.

cmosquer@unicauca.edu.co

ORCID ID: https://orcid.org/0000-0003-3906-6587

Received: April 29th, 2020. Accepted: August 23rd, 2020.

This article is licensed under a Creative Commons Attribution-Non-Commercial-No-Derivatives 4.0 International License. License Deed can be consulted at https://creativecommons.org/licenses/by-nc-nd/4.0. 
la expectativa de actualizarse en metodologías acordes con los lineamientos del Programa Nacional de Bilingüismo. Sería relevante que se consideraran estos resultados en las actividades de desarrollo curricular del programa de lenguas modernas y del desarrollo profesional de sus egresados.

Palabras clave: Enfoque, estrategias de enseñanza, método, metodología

\section{Introduction}

In 2017, the University of Cauca established, through an academic agreement, a mechanism to undertake follow-up processes, lead professional development programs, and facilitate the participation of graduates in academic and research projects, among other actions. In line with the provisions of this agreement (Acuerdo Superior 054, 2017), the Modern Languages Program of the University of Cauca found it relevant to carry out a research study that involved graduates. The project aimed at answering the following research question: What are the aspects that characterize foreign languages teaching of the Modern Languages Program Graduates from the University of Cauca? The research objectives were:

- To identify the methods and approaches that define graduates' teaching practices.

- To characterize the type of class strategies used by graduates in their practices.

- To analyze the needs and expectations of graduates with respect to methodologies in English language teaching.

The Modern Languages Program has contributed to the educational development of the region via preparing English and French language teachers for almost 48 years; nevertheless, one of the weaknesses found in self-evaluation processes has been the lack of follow-up concerning graduates' work, which has not allowed the identification of the methodologies applied and needs that they might encounter when teaching either of these foreign languages and thus respond to current bilingual guidelines in Colombia, regarding mostly to the achievement of the standards of competences, which apply mainly to teaching English. Also, the lack of follow-up of graduates has not allowed carrying out permanent feedback processes with the Program in order to strengthen actions in the pre-service training that help to meet the objectives stated within graduates' profile (Proyecto Educativo del Programa, 2017).

From the first contact with the graduates, they expressed they were currently working as teachers of English, and the research study focused only on methodologies in English language teaching. In order to characterize the methodologies applied by graduates in their teaching practices, questionnaires were used to yield information about teaching contexts, methods used, methodological strategies, criteria in the choice of methods and strategies, and needs and expectations in the implementation of methodologies. 
According to the results, the most used methods are the communicative and eclectic methods, which are also the most used in the integration of the four language skills (reading, writing, listening, and speaking) because of their characteristics. Among the strategies, the most used are discourse analysis, activities with authentic material, building-up stories, language games, conversation practices, and dramatizations.

Regarding the criteria in selecting methodological strategies, it was found that teachers consider important their role and that of the students', the development of research and problem-solving capacity, and the teaching context, primarily.

In relation to the expectations and needs in the implementation of methodologies, they focus on updating the design, and selecting and adapting teaching and learning materials; on methodological strategies, they focus on diagnosing and responding to students' learning needs, which are related also to their performance on the Saber 11 test".

Finally, carrying out this research study allowed characterizing graduates' teaching methodologies and undertaking actions that contribute both to their professional development and to strengthening the educational work of the Modern Languages program of the university.

\section{Literature Review}

In order to achieve a better understanding of some concepts addressed in the research study, theories from different authors were considered.

\section{Methodology and Approach}

Nunan (1999) states that methodology deals with pedagogical practices that include teaching techniques, classroom activities, and tasks that teachers design to enable students' learning. It should also be linked to methods in teaching which deal with specific perceptions as to how a language should be taught in order to strengthen the relationship between teaching practices and the methods and approaches grounding them. However, although some techniques proposed in different methods have been proven to be weak regarding the development of communication competences, many teachers continue basing their teaching

96 on these methods and approaches, without getting life-long learning on the students' part. For instance, the traditional approaches provide a good deal of knowledge about the language but do not develop in students the ability to use this knowledge to communicate appropriately, thus limiting the possibility of being exposed to the target language in the classroom, which is one of the few environments students have to use it.

The Saber 11 state test of secondary education must be taken by students who are finishing the eleventh grade, in order to obtain official results that allow them to pursue higher education. 
Regarding approach, Brown (2007, p. 17) points out that it refers to the "theoretical wellinformed positions and beliefs about the nature of language, learning, and the applicability of both to pedagogical settings", while methodology is referred to as "pedagogical practices in general (including theoretical underpinnings and related research)." Brown (2007) also states that they are the specific methods of addressing a task or a problem, as ways of acting to achieve a goal, or designs that are planned to control or manipulate information, which define teaching strategies.

\section{Language Teaching and Teaching Practices and Strategies}

Language teaching is considered to be dynamic and in continuous evolution. In regard to this, Bastidas (1993) states that language teachers are required to be updated and in search for innovative methodologies, strategies, and useful materials to make their teaching more effective for learners. However, in the teaching practice, different factors determine teachers' ways of working such as context and setting. Moreover, Richards and Lockhart (1994) point out that these factors influence teachers' decision-making about materials, methodologies, lesson planning, course goals, teaching methods, and assessment procedures, which may somehow make up teachers' teaching style. He also states that teaching can be described in terms of the actions, behaviors, and beliefs that teachers carry out in the classroom, and the effects of these on learners.

Teaching practices, then, depend on how much teachers are guided by routine or by self-inquiry and critical thinking. This is the reason why language teaching has gone through different and in some cases opposite perspectives along history, attempting to find an appropriate way of teaching; thus, leading to new methodological ideas and proposals for English as a foreign language (EFL) teaching.

Harmer (2007) provides a description of strategies that are implemented in the teaching of listening, speaking, reading, and writing; as well as linguistic components such as pronunciation, vocabulary, and grammar. Richards and Rodgers (1986, as cited in Bastidas, 1993) have contributed with extensive theory in the field of methodologies in language teaching, providing a detailed description of the trajectory in the implementation of different methods and approaches and the strategies proposed in each. Some of the most known teaching methods are Grammar-Translation, Direct, Audio-Lingual, Eclectic, and Communicative Language Teaching. Some approaches are Natural and Communicative.

\section{Learning Strategies and Styles}

These are considered important processes that facilitate and improve learning, and the teacher role is that of a guide for learners. The language taught for communicative purposes includes active use; that is, contextualized grammar and vocabulary to develop communication skills effectively. In addition, in the implementation of Communicative Language Teaching 
(CLT), students are exposed to interaction activities through authentic situations in the classroom, with student-centered activities included. Due to the characteristics of the CLT, the teacher is faced with major challenges in its implementation such as focusing on all of the components of communicative competence, engaging students in the use of the target language for meaningful purposes, focusing on fluency rather than accuracy (including having students rehearse situations they might encounter outside the classroom), guiding students in the development of strategies and learning styles, allowing learner-centeredness rather than teacher-centeredness, and creating classroom atmospheres that favor students' interaction and involvement (Brown, 2007).

\section{Common Methods and Approaches}

The following methods and approaches were considered in the current research study since in-service English teachers' teaching practices, in the department of Cauca, have mainly been grounded on the Grammar Translation Method (Encarnación \& Parra, 2010). Thus, exploring if this method still remains as one of the most used would be relevant. The other methods and approaches mentioned above (Direct, Audio-Lingual, Eclectic, Natural Approach, and CLT) were included because their characteristics emphasize the use of the target language in communicative situations, which is one of the aims in the pre-service training of the modern languages program.

The Grammar-Translation Method (GTM) was used to teach foreign languages focusing "on grammar rules as the basis for translating from the second language to the native language" (Brown, 2007, p. 18). Some of the characteristics of this method are the use of L1 to teach, not allowing much use to L2, grammar instruction focused on form, disconnected sentences from L2 into L1, content of texts overlooked, and little attention given to pronunciation. However, the GTM's strong emphasis on grammar analogies and rote exercises disregards the development of communicative skills in learners. In using this method, the teacher is expected to teach and the learner is expected to master; thereby, classes become teacher-centered as it is the teacher who mainly conducts all the activities, not allowing real communication among students. In regard to this, for Celce-

98 Murcia (2001), this method usually results in an inability to use the language effectively for communication.

Another method that emerged was the Direct Method. Bastidas (1993) states that this method is part of the so-called natural methods, which support that instead of focusing on grammatical rules, teaching should be geared towards using the L2 in the classroom. Also, Richards and Rodgers (1986, as cited in Brown, 2007) describe that in the Direct Method, instruction is given in the target language, the teaching of vocabulary and sentences is given 
in relation to everyday life, grammar is taught inductively, and pronunciation and listening comprehension are also considered in teaching.

Regarding the Audiolingual Method, Brown (2007) mentions that this method gives relevance to linguistic and psychological theory. Teachers are expected mainly to use the L2. Phonology and grammar should be given high priority rather than vocabulary. Among the methodological aspects that this method raises are the memorization of dialogues to avoid errors, and the comprehension and production of automatic utterances.

As for the Natural Approach, exposure to the target language is favored over the practice and production of this language. "Language is a vehicle for communicating meanings and messages" (Richards \& Rodgers, 1986, p. 130), "hence acquisition can take place only when people understand messages in the target language" (Krashen \& Terrell, 1983, as cited in Richards \& Rodgers, 1986, p. 130). According to these authors, the learner goes through three stages when immersed in the natural approach: the preproduction stage, early production, and speech, which are seen as a hierarchical process that is mastered through language exposure.

According to Bastidas (1993) eclecticism applied to the teaching of languages refers to choosing the best methodological proposals of the different methods in order to achieve the learning objectives. It is important to emphasize that those who choose to use this method know that it is not a random choice; this suggests that it is necessary to have previous knowledge of what each method proposes in order to opt for the best that can meet learning needs. In addition, according to the author, implementing the eclectic method implies the development of strategies and skills to reconcile methodological and procedural aspects, understanding the theories of language and learning nature, and if these can be evaluated and validated through practice.

The Communicative Language Teaching Method (CLT) focuses on the development of communicative competence, leading learners to explore real-life communication situations in the classroom and emphasizing not on linguistic accuracy as a priority, but on linguistic fluency. This method includes the implementation of tools that enable performance in the language not tested and leads to lifelong learning through authentic tasks.

In light of Bastidas (1993) the communicative approach contributed to the concepts of communicative competence and the study of language from the social aspect. In this sense, it focuses on the study of language in interaction, which implies considering sociolinguistic rules in which culture and meaning are framed in a relevant way.

Cárdenas (2007, as cited in Cárdenas et al, 2015) classifies the methods and approaches that have emerged chronologically for language teaching, as follows: 


\begin{tabular}{|c|c|c|}
\hline Categories & Author & Method/Approach \\
\hline $\begin{array}{l}\text { Centered on } \\
\text { language }\end{array}$ & $\begin{array}{l}\text { Richards, } 1984 \\
\text { Kumaravadivelu, 2003-2006 }\end{array}$ & $\begin{array}{l}\text {-Grammar-Translation Method; Aural- } \\
\text { Oral method, Audio-Visual Method; } \\
\text { Lexical-Structural programs. } \\
\text { Audio-Oral Method } \\
\text { Cognitive Code }\end{array}$ \\
\hline $\begin{array}{l}\text { Centered on } \\
\text { the learner }\end{array}$ & $\begin{array}{l}\text { Richards, } 1984 \\
\text { Kumaravadivelu, 2003-2006 }\end{array}$ & $\begin{array}{l}\text {-Humanistic approaches (Silent } \\
\text { Way, Total Physical Response, } \\
\text { Community Language Learning, } \\
\text { Suggestopedia); Natural Approach. } \\
\text {-Communicative Approach }\end{array}$ \\
\hline $\begin{array}{l}\text { Based on science } \\
\text { and research }\end{array}$ & \multirow{3}{*}{$\begin{array}{l}\text { Richards, } 2002 \text { based } \\
\text { on Zahorik } 1986\end{array}$} & Suggestopedia \\
\hline $\begin{array}{l}\text { Based on theories } \\
\text { and philosophies }\end{array}$ & & $\begin{array}{l}\text { Silent Way, humanistic approaches, } \\
\text { Communicative Approach }\end{array}$ \\
\hline $\begin{array}{l}\text { Based on teachers' } \\
\text { ability and } \\
\text { personality }\end{array}$ & & Eclecticism \\
\hline Centered on learning & Kumaravadivelu, 2003-2006 & Natural Approach \\
\hline Non-Methods & Kumaravadivelu, 2006 & $\begin{array}{l}\text { Silent Way, Respuesta Física } \\
\text { Total, Suggestopedia, Community } \\
\text { Language Learning }\end{array}$ \\
\hline
\end{tabular}

According to Nunan (1999, as cited in Cárdenas et al, 2015), traditional methods and approaches have been re-evaluated and re-considered according to the contemporary epoch. As a result, communicative approaches emerged giving way to learner-centered education, negotiation of curriculum, task-based teaching, relevance of learning strategies and styles, diverse trends in evaluation strategies, extracurricular activities, and classroom management.

Likewise, Kumaravadivelu (1994, as cited in Cárdenas et al, 2015) points out that new ideas were introduced regarding language teaching in the $90 \mathrm{~s}$, according to the demands of the new era such as going beyond the concept of method to look for effective teaching strategies and teacher training. That reconceptualization of methods suggests the search for teaching methods that allow teacher autonomy based on a permanent reflection upon theory and practice. In this sense, "through autonomy, continuous learning, research and responsibility, teachers are empowered to theorize their practice, make innovations in their 
particular teaching contexts, and propose new teaching strategies" (Cárdenas et al, 2015, p. 100).

All the methods and approaches briefly described above give account of the purposes in language teaching regarding language focus, strategies, techniques, learning context, and learning objectives. In the Colombian context, it can be mentioned that in a questionnaire applied by the Ministry of Education to explore in-service teachers' methodologies, it was found that teachers use the Communicative Approach, as well as Content and Language Integrated Learning (CLIL). Besides, the results showed a focus on the development of competences, strategies, and strategy instruction. Among the strategies are "scaffolding, role play, fill-in the blanks, project-based development, listening activities, games, reading, videos, Total Physical Response (TPR)" (MEN, 2016, p. 27).

\section{Methodologies and the National Bilingual Program}

In addition, the National Bilingual Program (NBP) (2018-2022) has taken actions aimed to improve students' English level and thus ensure complete educational paths, strengthen English teachers' teaching practices, create spaces that allow the use and exposure to the target language, promote the design of appropriate teaching resources, and promote pedagogical actions to meet the expected goals. However, because of the real conditions in which foreign languages are taught in Colombia, such as the limited number of hours, the lack of resources, the low exposure to the target language in real communicative situations, and the low number of qualified teachers, whether this country is ready to face the challenging policy of Colombia bilingual is questionable (Cardenas, 2006, as cited in Cárdenas et al, 2011). These educational policies in language teaching are commonly not in accordance with real learning needs but are underpinned by political and economic agendas rather than by pedagogical factors (Usma, 2009, as cited in Peláez \& Usma, 2017). In addition, De Mejía (2007, as cited in García \& García, 2012) sustains that the goals of the NBP are to be achieved mostly by private schools because they are sponsored by different organizations and supported by their own resources; factors that seem not to be considered in the educational policies. Another aspect is that although the NBP 2018-2022 affirms that it is their interest to foster the learning of other languages such as French and Portuguese, referred to as third languages grounded on a functional multilingual focus, and that Colombia is a multicultural and multilingual country because of the native and creole languages, the actions taken in terms of materials, resources, guidelines, immersion programs, and strengthening projects in different regions are addressed only to the English language. Guerrero (2010, as cited in García \& García, 2012) pointed out that English, in Colombia, is the language that has been given all the attention for investment. 
In order to support the policy of standardization in secondary school, the Suggested Curriculum designed by the Colombian Ministry of Education (2016) aims to provide the educational community and the different actors of society with a flexible and open curriculum that acts as input for planning, implementation, assessment and evaluation of the English curriculum in schools nationwide. This document expresses that English is the foreign language which the national government is committed to in order to have a bilingual country competitive at an international level (MEN, 2016, p. 15). The methodology proposed in the suggested curriculum for sixth to eleventh grades aims to develop language skills, to promote a problem-solving approach, and to implement task-based and project-based activities" (MEN, 2016, pp. 33-35). The Proyecto Tipo, of the National Plan of Development 2018-2022, issued by the National Department of Planning (2018), expresses that elementary and high school students' communicative competences are not developed, which hinders their opportunity to interact in the globalized world, to identify cultural and linguistic differences, and to apply for international educational experiences. Therefore, three objectives have been stated to face this problem; namely, enhance English teaching and learning by strengthening pedagogical actions, foster the development of teachers' language skills and competences, and strengthen teachers' and students' exposure to the target language in real communication contexts.

The Suggested Curriculum for English focuses on the development of communicatively competent citizens aware of sociocultural aspects of the country, and it expresses that "the vision of this curricular proposal regarding learning languages focuses on the sociocultural theory. Learning originates within social activities developed in a plane that is external to the individual and that promotes cooperative environments" (Vygotsky, 1978, as cited in MEN, 2016, p. 22). In contrast, teaching methodologies in Colombia, shaped by the guidelines suggested by MEN, do not allow teachers to be autonomous enough to propose what they think should work better in their teaching contexts since institutional goals are mainly addressed to improving the Saber 11 Test results. González (as cited in Cárdenas et al., 2011) states that in Colombia a focus should be placed on professional development rather than on teacher training because the latter suggests an implementation of similar methodologies no matter how different teaching and learning contexts are.

According to Kostina and Hernández (as cited in Cárdenas et al, 2015), foreign language teachers' professional development involves professional competence which deals with pedagogical, communicative, methodological, intercultural, and investigative competence. These five competences deal with being able to organize and conduct the pedagogical process, to know what to teach, to manage teaching techniques and strategies, to use the target language effectively, to conduct teaching and learning appropriately, to apply techniques, methods, and approaches, to know students' learning styles and strategies, to adapt their teaching to the learning conditions, to recognize and identify their own beliefs and those of their students, to listen to students' opinions, and to consider students' cultural traits. 
In this sense, foreign language teachers are called upon to evidence both a communicative competence and lastly, a teaching competence in their teaching.

\section{Type of Research}

This research followed a mixed approach type since it comprises both a qualitative and a quantitative approach. According to Wallace (1998), the quantitative approach is mainly used to describe what can be counted or measured objectively, whereas the qualitative approach is used to describe data that cannot be counted or measured objectively. In the mixed approach, there are characteristics of the two approaches so that they complement each other to give reliability to the data emerging from the research that aimed to characterize the teaching methodologies of graduates from the modern languages program of the University of Cauca.

\section{Participants}

After some calls by email and a personal invitation during an event held by the Modern Languages Program, thirty-two graduates, who work either in the public or private sector at different schools in Cauca and other departments in Colombia, showed interest in taking part in the research study. This was helpful because teachers responded to the questionnaires when asked, which permitted the data collection within the time planned.

\section{Data Collection}

In order to collect the data, four questionnaires were designed and applied at different moments of the research; that is, taking into account the teachers' availability to answer them. These instruments contained questions that could help get information regarding graduates' teaching methodologies. A broader explanation of the purpose using each of the questionnaires is presented in the section Results in this article.

\section{Questionnaire One}

This questionnaire aimed to explore graduates' teaching contexts, professional experience, and qualifications. It served to gather information on teachers' actions to grow professionally, characterize teaching and learning conditions, and identify possible difficulties in their teaching practices.

\section{Questionnaire Two}

As well as with the first questionnaire, one of the sections of this data collection instrument was devoted to finding out information about teachers' teaching experience and professional development activities, anticipating that some teachers might not want to take 
part in the research from the beginning to the end for the lack of interest or time. The other section explored teachers' beliefs and attitudes toward teaching, the frequency of taking part in school activities, characteristics of a regular class, and frequency in the use of approaches. This section aimed to analyze teaching practices, activities, beliefs, and attitudes, and how these vary according to the characteristics of teacher training. Through this questionnaire it was possible to better understand teachers' criteria for the use of teaching strategies (OECD Teaching and Learning International Survey (TALIS), n.d.).

\section{Questionnaire Three}

This questionnaire was used to identify the methods and approaches grounding teaching methodologies and strategies used during the implementation of the methods. Some questions were taken from Abbasi's (2011) Survey of Teaching Strategies in [the] ESL Classroom.

\section{Questionnaire Four}

By means of this data collection instrument, it was possible to go deeper into the criteria teachers have to select methods and teaching strategies, to know about their teaching needs and expectations when they implement teaching methodologies, and to plan on strategies that the modern languages program — together with the local boards of Education-could implement in order to meet those needs and expectations of the teachers.

\section{Data Analysis}

The research question inquired about the aspects that characterize English teaching methodologies of graduates from Cauca University and was approached from the contextualization of teaching practices, the identification of methods and approaches that define those practices, the criteria taken into account in curriculum design, a description of classroom activities, the criteria for selecting methods and strategies, and graduates' needs and expectations regarding teaching methodologies. The qualitative data that emerged from open questions were grouped and categorized according to commonalities, and analyzed in light of the research question. As for the quantitative data, these were analyzed according to the percentages obtained, which could tell about teachers' trends in teaching methodologies.

\section{Results}

\section{Questionnaire 1}

This questionnaire aimed to get information about the teachers' teaching contexts, either elementary, high school or university, their professional experience, and qualifications. 
This information helped to know how updated the teachers were regarding teaching methodologies, the area of influence of their practices, and work stability.

Table 1. Teachers' Teaching experience and Qualifications

\begin{tabular}{|c|l|c|c|}
\hline $\mathbf{N}^{\circ}$ & \multicolumn{1}{|c|}{ Descriptor } & $\begin{array}{c}\text { Percentage } \\
\%\end{array}$ & $\begin{array}{c}\text { No of } \\
\text { Teachers }\end{array}$ \\
\hline 1 & Teachers without any master's degree & 65 & 20 \\
\hline 2 & Teaching experience longer than six years & 43 & 13 \\
\hline 3 & Master's degree in Language teaching or related & 18 & 5 \\
\hline 4 & $\begin{array}{l}\text { Teachers working at either } \\
\text { elementary or high school }\end{array}$ & 78 & 24 \\
\hline 5 & Teachers working in Cauca Department & 91 & 29 \\
\hline 6 & Full-time teachers & 82 & 26 \\
\hline
\end{tabular}

Table 1 shows only the results with the highest percentages obtained, because each question contained more than one option to answer it. It can be observed that most of the participating teachers $(91 \%)$ work in the department of Cauca, which means graduates are helping to respond to learning demands in the region, which is one of the main objectives of the University of Cauca. In addition, the highest percentage of teachers work in either elementary or high schools, so they are required to follow the suggested national policies of the curriculum no matter what their teaching and learning environments are like. Therefore, teachers are called upon to adapt and implement the suggested curriculum introduced by the Ministry of Education. It is important to mention that most of the graduates (26) work as full-time teachers which guarantees permanence to undertake follow-up and evaluation processes of their teaching practices in the same teaching contexts.

\section{Questionnaire 2}

This questionnaire focused on the most used methods and approaches of the participating teachers in the integration of the four language skills (speaking, writing, reading, and listening) and methods of preference. Results show that regarding all of three aspects, the methods with the highest incidence are the Communicative Language Teaching Method (34\%), and the Eclectic Method (33\%). It was also found that graduates use the Natural Approach (6\%). The methods with the lowest incidence are the Grammar-Translation Method (9\%), the Total Physical Response Method (6\%), the Audio- Lingual Method (3\%), and the Direct Method (3\%). Despite these results, the teachers use mostly the methods that they prefer. The teachers' knowledge of the definitions and implications of English methods can be guaranteed because during the pre-service training in the modern languages program, 
they were allowed the opportunity to get familiarized with different theories that approach the subject matter. Figure 1 presents the methods and the approach used by the participating graduates, Figure 2 shows the methods and the approach they use to integrate the language skills, and Figure 3 presents the methods graduates prefer in the English language teaching practices.

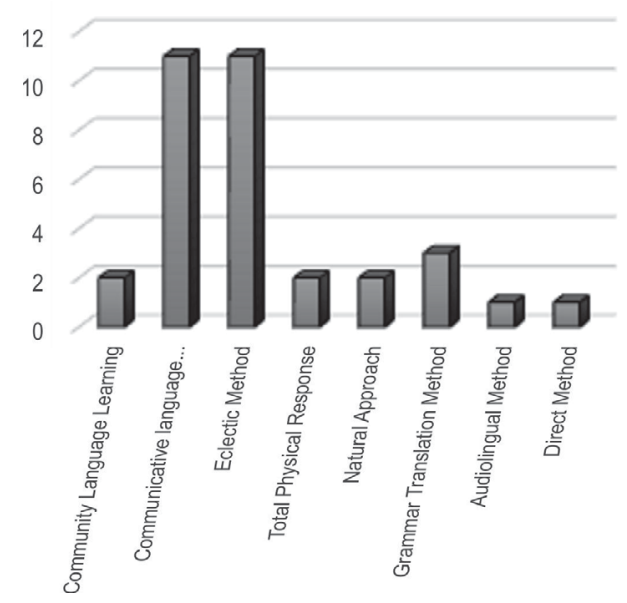

Figure 1. Methods used

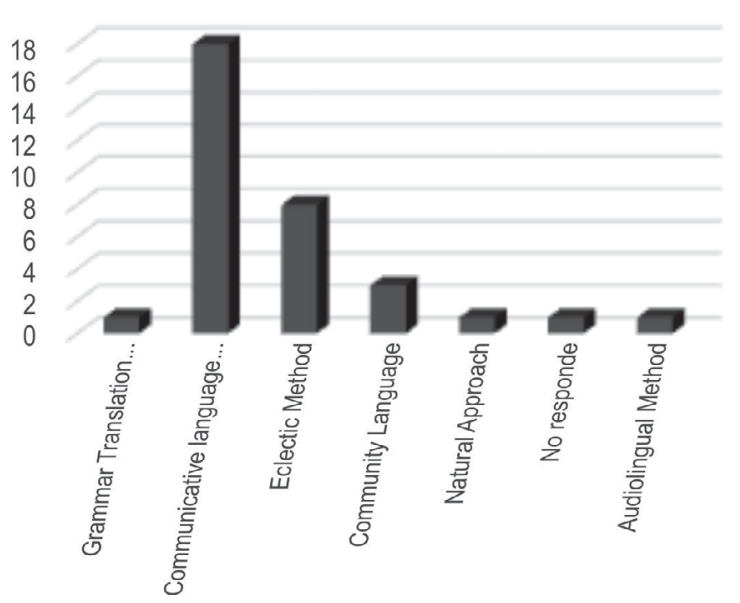

Figure 2. Methods and approach used in skills integration 


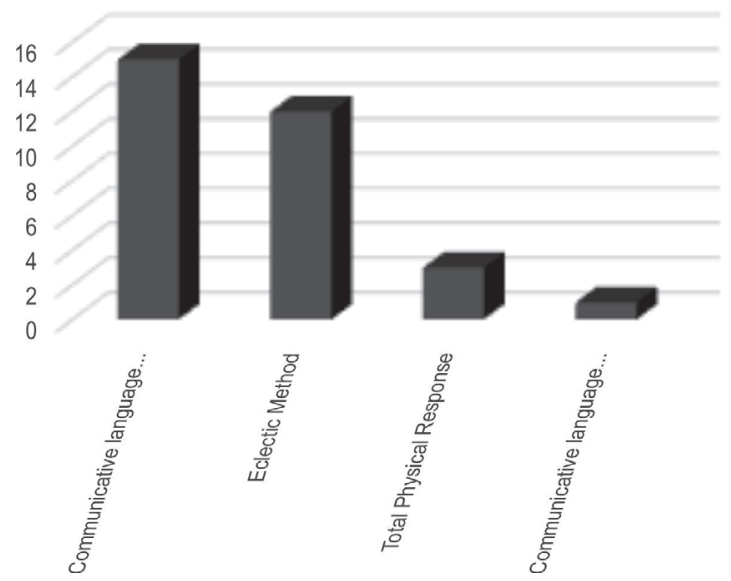

Figure 3. Methods of preference

Through the second questionnaire, data on the strategies used in the implementation of methods were also gathered. Taking into account that, on the one hand, reviewing methods and approaches is part of the pre-service training; and on the other hand, that in 2007 and 2015, teachers from the Cauca region were offered a series of workshops on the implementation of standards and the suggested curriculum by the Ministry of Education, a list of different strategies was included in the survey for each method according to its characteristics. Table 2 below shows only the strategies with the highest percentage in each of the most used methods and approaches by the participating teachers.

As for the Communicative Language Teaching Method, students should be allowed the opportunity to interact, to negotiate meaning and to develop fluency rather than accuracy. Results in Table 2 show that the strategy most used by the teachers when they ground their teaching in this approach is language games, which in fact is the strategy with the highest percentage among all the strategies in the list of the methods described. Regarding the strategies that the teachers use with the eclectic method, appear games, reading comprehension, questions and answers, songs or dialogs completion, description of experiences, storytelling, running dictation, fill in the blanks, reading-translation exercises, picture trip story, presentations, role-plays, writing exercises, and matching. However, the use of strategies depends on the topic, teaching context, learner needs, and previous knowledge. The following are some comments made by the teachers in the second questionnaire, with respect to the strategies they use: 
Table 2. Strategies developed with the most used methods/approaches

\begin{tabular}{|c|l|l|c|c|}
\hline $\mathbf{N}^{\circ}$ & \multicolumn{1}{|c|}{ Method/Approach } & \multicolumn{1}{|c|}{ Strategy developed } & $\begin{array}{c}\text { Percentage } \\
\mathbf{\%}\end{array}$ & $\begin{array}{c}\mathbf{N}^{\circ} \text { of } \\
\text { Teachers }\end{array}$ \\
\hline 1 & $\begin{array}{l}\text { Communicative } \\
\text { Language Teaching }\end{array}$ & Language games & 71.9 & 23 \\
\hline 2 & Audio-lingual & Completing a dialogue & 36.7 & 11 \\
\hline 3 & Direct Method & Question and answer exercises & 36.7 & 11 \\
\hline 4 & Grammar Translation & $\begin{array}{l}\text { Reading comprehension } \\
\text { questions }\end{array}$ & 23.3 & 7 \\
\hline 5 & Silent Method & Spelling Dictation & 46.4 & 14 \\
\hline 6 & Total Physical Response & Singing a song and acting out & 53.3 & 17 \\
\hline 7 & Natural Approach & Problem solving activities & 50 & 16 \\
\hline 8 & $\begin{array}{l}\text { Community Language } \\
\text { Learning }\end{array}$ & Focusing on vocabulary & 34 & 10 \\
\hline
\end{tabular}

T1: "Utilizo diferentes estrategias que dependen del contexto de los estudiantes. Por lo general me gusta combinar varios métodos de enseñanza en la clase. Los métodos que más me han ayudado a cumplir con los objetivos propuestos han sido communicative language teaching y TPR".

T2: "Según la temática me permito realizar actividades especificas de otros métodos, teniendo en cuenta los conocimientos previos de los estudiantes y el progreso en cada una de sus habilidades"'.

In some cases, students' needs are limited to learning only about what they will be faced with in the Saber Pro Test, as one teacher expressed:

T3: "Trato de enfocarme en las necesidades de mis estudiantes. [...] comprensión de lectura para la presentación de pruebas Saber. [...] diálogos dependiendo a tiempo verbal dado, hacer tests de gramática en laboratorio y llevar su cuaderno de control de vocabulario nuevo. Y se espera seguir trabajando comprensión de lectura en gran medida"s.

\section{Questionnaire 3}

The implementation of this data collection technique aimed to inquire about the criteria in the curriculum design, professional development activities, and the impact of

3 I use different strategies that depend on the students' context. I generally like to combine various teaching methods in class. The methods that have helped me the most to meet the proposed objectives have been communicative language teaching and TPR.

4 Depending on the subject, I allow myself to carry out specific activities from other methods, considering the students' previous knowledge and their progress in each of their skills.

5 I try to focus on my students' needs. [...] reading comprehension to take the Saber test. [...] dialogues depending on the given verb tense, taking grammar tests in the language laboratory, and keeping a control notebook with new vocabulary. I expect to continue working on reading comprehension to a great extent. 
these activities on the participating teachers' professional practice. This questionnaire also inquired about the beliefs that influence their actions, as well as their curricular activities and description of a class.

Regarding professional development activities, when the teachers were asked about their participation in seminars, conferences, courses, and the impact it had had on their teaching practices, results show that for only $44.8 \%$ of the teachers, the impact had been good. This suggests that there is a lack of professional development courses pertinent to learning and teaching needs in the Cauca region, where most of the participating teachers work. Unfortunately, although different training courses had been offered by the University of Cauca for seven years in a row, through agreements signed with the local boards of Education, the effort made by the university to continue offering these courses has been rather fruitless since 2013, when a training course was offered to both elementary and high school teachers. However, in 2019 the Modern Languages Program led a series of workshops in order to contribute to in-service teachers' professional development as an initiative based on the findings of the present research study.

Some beliefs that the teachers mentioned, which lead their teaching (Annex 1) are the importance of exposing students to problem solving tasks, promoting their research capacity, implementing student-centered teaching, defining standards of competences to measure students' language levels, promoting students' participation, and having a command of the concepts on foreign language teaching.

The sources of the teachers' beliefs are teachers' experience as language learners, experience from teaching, teachers' personality, education-based, or research-based principles. The four aspects considered by the teachers among their beliefs are approached in the languages program as they are relevant in students' integral development and the educational process in general (Kindsvatter et al, 1988; Abdi \& Asadi, 2011, as cited in Pourhosein \& Banou, 2017).

Another important aspect included in Questionnaire Three was teachers' curricular activities among which were found participation in curriculum design, materials selection, and exchange of materials with peers, as well as monitoring students, implementation of evaluation strategies, professional learning activities, and participation in school projects. Eighteen out of thirty-two teachers never carry out peer observation. This finding gives evidence of a need for adopting self-evaluation processes based on external views, in this case from peers, either from the same school or another, which could help make relevant changes in the curriculum through teamwork, and this way improve the teachers' teaching practices. Both novice and experienced teachers can benefit from peer observation as they can learn from each other about how to deal with students' learning, how to resort to effective 
teaching strategies, make reflections upon teaching, share ideas on teaching methodologies, and discuss problems (Richards \& Farrell, 2005).

In order to go deeper into curricular design activities, some questions that would describe the teachers' specific classroom activities were asked in Questionnaire 3 (Annex 2). This section contained 24 questions grouped according to their commonalities, among which were: presentation of topics, learning objectives, monitoring and feedback of students, interaction patterns, student level, follow-up of students' learning, and use of instructional strategies. Regarding the presentation of topics, it was found that the tendency is to present a new topic frequently, to promote students' participation, and to follow topic sequence. Regarding learning objectives, findings revealed that these are set up in accordance with students' performances; that is, what students are capable of doing with their learning. Feedback and monitoring spaces are given by reviewing assigned tasks. Also, classroom interaction occurs mainly when activities are done through cooperative work. To approach students' level, varied activities are performed but not frequently, being exams and tests the main assessment instruments used, besides self-assessment and reflection. Regarding instructions given to students, these are reviewed often and activities are developed trying to integrate the language skills.

To complete the data collection process, a fourth questionnaire was implemented, in which only sixteen graduates participated, which means that the sample was not stable. This instrument was meant to explore the teachers' criteria for selecting teaching methods and methodological strategies, teachers' needs when implementing methodologies, especially those suggested by the NBP in the Suggested Curriculum guidelines addressed to sixth to eleventh grades, and their expectations to improve those methodologies.

As for the criteria for selecting methods, the teachers find it important to consider students' learning needs, the relevance of the methods used in the teaching context, teachers' own learning experiences, and how familiar they are with the methods so as to use them appropriately, according to the syllabus. With respect to the criteria for selecting methodological strategies, it was found that relevance in the context takes on importance as well as the teachers' learning experiences and available resources and materials, as shown in Figure 4 below.

In addition, findings showed that the teachers have some needs when they implement methodologies proposed in the Suggested Curriculum for English. Most of them are related to not knowing how to articulate teaching practices for the performance expectations in the Saber 11 Test; that is, there is no correspondence between what is taught and what is evaluated on this test. Similarly, some of the teachers believe that they need to get familiar with methodological strategies in line with students' learning needs which, unfortunately, are seen by the teachers only from the perspective of helping students to get good results on 


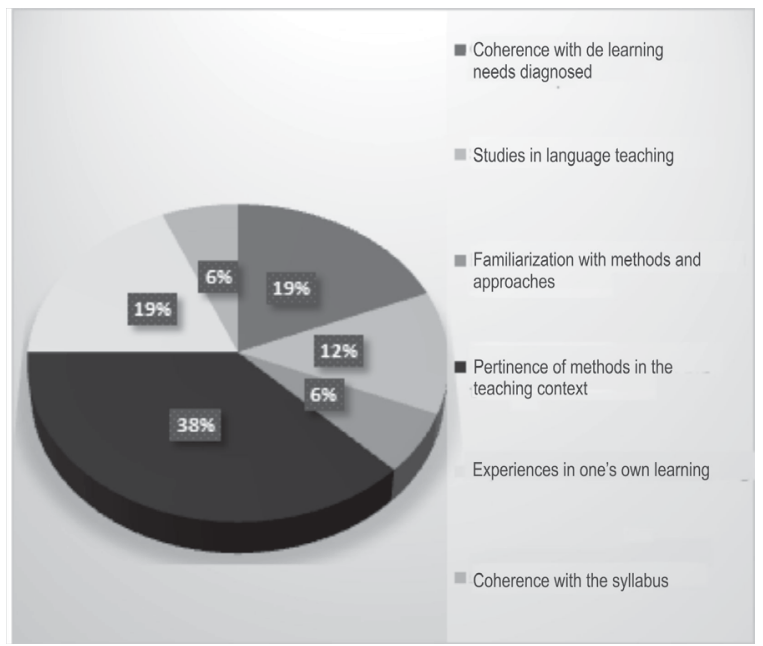

Figure 4. Criteria in methods selection.

the Saber 11 Test. Regarding actions to improve methodologies, the teachers expect to be updated in order to respond to the guidelines stated in the NBP, to help students to perform better on the Saber 11 Test, to get familiar with teaching strategies that meet learning needs, and to be trained in materials design, selection and adaptation. Figures 5 and 6 show the results.

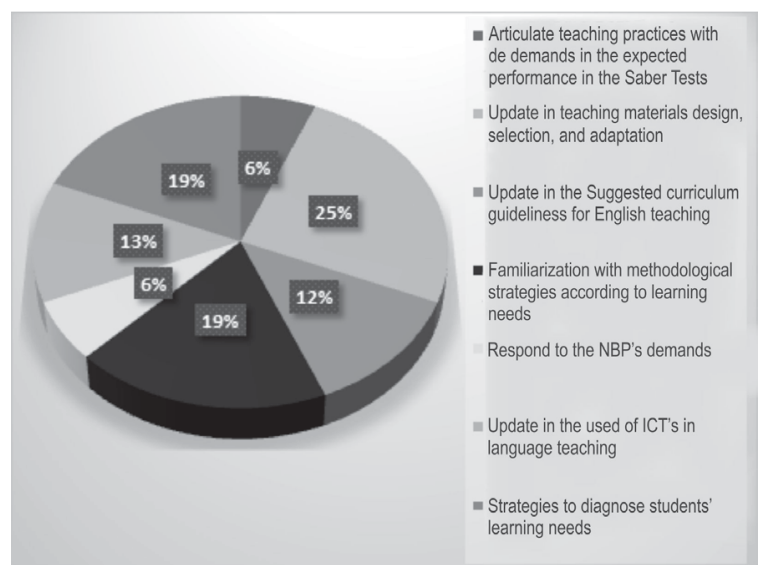

Figure 5. Needs implementing methodologies according to the NBP guidelines 


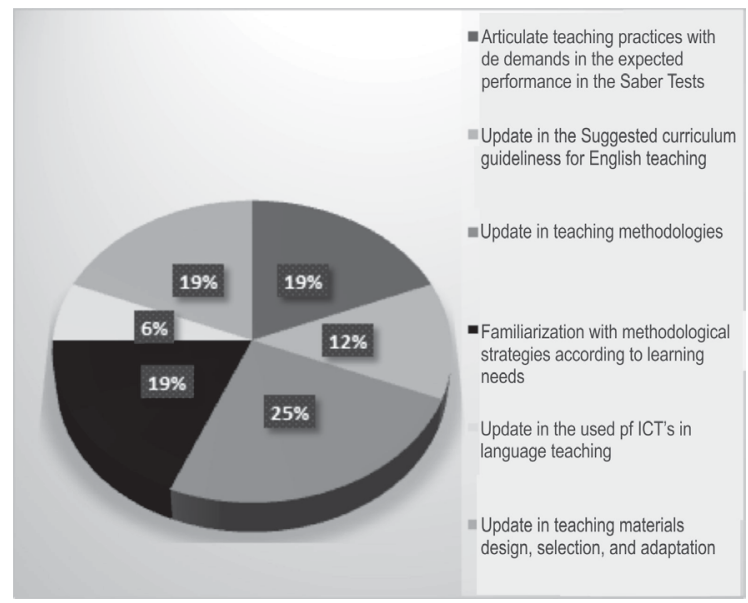

Figure 6. Expectations to improve the implementation of teaching methodologies

\section{Conclusions}

The present research study focuses on characterizing the methodologies that foreign language graduates of the University of Cauca apply in their teaching practices. The research question was based on the contextualization of their teaching contexts, the identification of methods and approaches that define their teaching practices; the criteria that they consider in curriculum design; classroom activities; the criteria they follow for selecting methods and strategies; the teachers' needs regarding the methodologies to respond to bilingualism, and the expectations about teaching methodologies. The following are some conclusions drawn upon the results obtained.

Most graduates have completed only undergraduate studies and have been teaching for more than six years. Less than $50 \%$ of the teachers have a master's degree in teaching languages or related subjects. These results show the need to offer graduate programs in order to promote research and through which teachers can update their knowledge about language teaching and grow professionally.

The most used methods and approaches that graduates prefer are the Communicative Language Approach and the Eclectic Method. The former defends that language is the expression of meaning and that the primary function of language is interaction and communication. The latter is framed in taking what is most appropriate of other methods to the learning needs and characteristics of the learning context, from which teaching strategies are also chosen. In this sense, the teachers are challenged to carry out diagnoses 
on students' English language proficiency level for making further decisions on contents, strategies, materials, activities, and so on. There is, then, a relationship between training and teaching in relation to pedagogical and didactic aspects. In addition, the teachers' conception of language, and how it is learned, is based on students' learning needs, which are identified through diagnoses.

The methods that the teachers choose to integrate language skills are consistent with the previous point. Most graduates opt for the implementation of the Communicative Language Teaching Method and the Eclectic Method as they expose students to L2 situations like those they might find in real life, and in which the four language skills (speaking, writing, listening, and reading) are not fragmented but integrated. Here, teachers' roles become relevant regarding pedagogical practices that include teaching techniques, classroom activities, and tasks so that students take advantage of their own learning (Nunan, 1999, as cited in Encarnacion \& Parra 2010, p. 30).

In relation to the use of methods and the strategies used with these methods, the following was found:

- Grammar-Translation Method: Reading comprehension questions, translation of a literary passage and deductive application of grammar rules are mainly carried out. Direct Method: question and answer exercises and conversation practices.

- Audio-Lingual Method: Activities to complete and memorize dialogues.

- Eclectic Method: The teachers resort to strategies used in other methods according to the topic and the learning context, as well as students' needs, communicative competences, and previous knowledge.

- Regarding the Natural Approach: Games and role plays.

- Communicative Language Teaching: Speech analysis, activities with authentic material, creation of stories from a sequence of images, and language games.

Among the criteria taken into account in curriculum design, which were approached from the beliefs that define the teachers' teaching practices, the results show that the teacher and student roles go in line with the student-centered learning environment. Curricular design is also defined by the teachers' interest in promoting students' research capacity and problemsolving strategies. Based on this criterion, the actions in curricular design determine what is taught (the contents), where (the context), to whom (the learners), when (the sequences), how (the methodological strategies), why (the purpose), and how it is evaluated (the evaluation), as stated by De Zubiría (2013). As the language program puts it, it is important to create spaces for the development of critical and investigative thinking that allows graduates to face educational challenges in the best possible way; thus, contributing to the development and transformation of society. 
The last criterion in curricular development that is also based on teachers' beliefs is that, in language learning development, communicative competence becomes one of the most important aims, so the learning environment cannot be silent. Therefore, teachers have privileged the communicative language teaching method and strategies that prioritize interaction.

Regarding curricular design two aspects were found, which would need a greater emphasis on the teachers' part when it comes to monitoring students' learning: personalizing teaching and assigning extra class work, since these allow the opportunity to diagnose learning needs, level of individual performance, rethinking of methodologies, and contact with the target language outside of class.

With respect to the description of a particular class, it can be concluded that participation is promoted among students, previous knowledge is part of input activities, learning objectives are related to their performance, topics are sequenced, there is feedback and monitoring, activities are varied in order to respond to different learning styles and paces, and lastly, self-evaluation and reflection upon the learning process is enhanced.

According to the findings, the graduates find it important to implement methodologies according to the teaching and learning context, to their own learning experiences, and to the resources available when referring to the criteria for selecting methodological strategies. These criteria correspond to the importance of teacher training and the fundamental role of materials and resources in learning.

As for criteria for selecting methods to be implemented, a great relevance is given to the teaching context, followed by coherence with the learning needs diagnosed and the learning experiences. These results demonstrate that, for the graduates, teaching takes on weight when it focuses on the learning environment and the learner. However, most teachers expressed they needed to update on strategies to diagnose learning needs, along with carrying out action research projects.

In order to articulate methodologies with the current demands on bilingualism, it was found that teachers' greatest need has to do with updating on design, selection, and adaptation of materials, followed by familiarizing themselves with methodological strategies in line with learning needs and strategies to diagnose those needs. It should be mentioned that the material provided by the MEN contains a large number of methodological strategies, activities to address the four language skills, and techniques for the use of materials; however, it is teachers' responsibility to adapt these resources to the learning context and, consequently, to students' needs in order to enable better results in both teachers' and students' performances. 
Finally, updating on topics related to teaching methodologies is described as the main expectation of most teachers, followed by articulating teaching practices for the requirements established in the Saber 11 tests, using teaching strategies according to students' learning needs, and familiarizing themselves with materials design and information and communication technologies.

\section{References}

Abbasi, A. (2011). A survey of teaching strategies in ESL classroom Language in India: Strength for today and bright hope for tomorrow. Language in India, 11, 313-329.

Acuerdo Superior No. 054 de 2017 (Por el cual se establece la Política de Egresados en la Universidad del Cauca).

Bastidas, J. (1993). Opciones metodológicas para la enseñanza de idiomas. JABA Ediciones.

Brown, D. (2007). Teaching by principles: An interactive approach to language pedagogy. Longman and Pearson Education.

Cárdenas, M. L., et al. (2011). Cobertura vs Continuidad: Dos retos para el desarrollo profesional para los docentes de inglés en el marco de Colombia bilingüe. In J. A. Bastidas \& G. Muñoz (Eds.), Fundamentos para el desarrollo profesional de los profesores de inglés (pp. 119-154). Universidad de Nariño.

Cárdenas, R., et al. (2015). Implementación del programa nacional de bilingüismo Cali-Colombia. Universidad del Valle.

Celce-Murcia, M. (2001). Teaching English as a second or foreign language. Heinle \& Heinle Publishers.

De Zubiría, J. (2013). Cómo diseñar un currículo por competencias. Editorial Magisterio.

Departamento Nacional de Planeación (2018). Fortalecimiento de las competencias comunicativas en inglés de los estudiantes de los Establecimientos Educativos oficiales. Proyecto Tipo. https://proyectostipo. dnp.gov.co/index.php?option $=$ com_k2\&view $=$ item\&id $=239$ :fortalecimiento-de-las-competencias-comunicativas-en-ingles-de-los-estudiantes-de-los-establecimientos-educativosoficiales\&Itemid $=110$

Encarnación, C., \& Parra, A. (2010). State of the English teaching in high schools in Popayán [Unpublished master's dissertation]. Universidad de Caldas.

García, J., \& García, D. (2012). Políticas lingüísticas en Colombia: tensiones entre políticas para lenguas mayoritarias y lenguas minoritarias. Boletín de Filología, 47(2), 47-70.

Harmer, J. (2007). How to teach English. Pearson Education Limited.

Ministerio de Educación Nacional (2016). Orientaciones y principios pedagógicos currículo sugerido de inglés. http://aprende.colombiaaprende.edu.co/sites/default/files/naspublic/Anexo\%2014\%20 Orientaciones $\% 20 \mathrm{y} \% 20$ principios $\% 20$ Pedagogicos.pdf

Ministerio de Educación Nacional (2018). Programa Nacional de Bilingüismo 2018-2022. http:/ /aprende.colombiaaprende.edu.co/es/colombiabilingue/86718 
Nunan, D. (1999). Second language teaching and learning. Heinle \& Heinle Publishers.

OECD Teaching and Learning International Survey (TALIS) (n.d.). Teacher Questionnaire, 14-15. http://www.oecd.org/education/school/TALIS-2008-Teacher-questionnaire.pdf

Peláez, O., \& Usma, J. (2017). The crucial role of educational stakeholders in the appropriation of foreign language education policies: A case study. Profile: Issues in Teachers' Professional Development, 19(2), 121-34. http://dx.doi.org/10.15446/profile.v19n2.57215

Pourhosein, A., \& Banou, N. (2017). English language teaching. Canadian Center of Science and Education, 10(4), 78-86. https://eric.ed.gov/?id=EJ1133207

Proyecto Educativo del Programa (2017). Programa de Lenguas Modernas con Énfasis en Inglés y Francés. Universidad del Cauca.

Richards, J., \& Lockhart, C. (1994). Reflective teaching in second language classrooms. Cambridge University Press.

Richards, J., \& Rodgers, T. (1986). Approaches and methods in language teaching. Cambridge University Press.

Richards, J., \& Farrell, T. (2005). Professional development for language teachers. Cambridge University Press.

Wallace, M. (1998). Action research for language teachers. Cambridge University Press. 


\section{Annex 1. Teacher beliefs}

\begin{tabular}{|c|c|c|c|c|c|c|}
\hline & $\begin{array}{l}\text { Creencias que definen las } \\
\text { acciones }\end{array}$ & $\begin{array}{l}\text { Totalmente } \\
\text { de } \\
\text { acuerdo } \\
\%\end{array}$ & $\begin{array}{c}\text { De } \\
\text { acuerdo } \\
\%\end{array}$ & $\begin{array}{c}\text { En } \\
\text { desacuerdo } \\
\%\end{array}$ & $\begin{array}{c}\text { Totalmen- } \\
\text { te en } \\
\text { desacuerdo } \\
\%\end{array}$ & $\begin{array}{l}\text { No } \\
\text { responde } \\
\%\end{array}$ \\
\hline 1 & $\begin{array}{l}\text { Un docente eficaz demuestra } \\
\text { la forma correcta para } \\
\text { solucionar un problema }\end{array}$ & 13 & 59 & 19 & 3 & 3 \\
\hline 2 & $\begin{array}{l}\text { Cuando se trata de bajo } \\
\text { desempeño, me refiero a un } \\
\text { desempeño que no alcanza } \\
\text { el nivel de logro esperado }\end{array}$ & 13 & 75 & 6 & - & 6 \\
\hline 3 & $\begin{array}{l}\text { Es mejor cuando es el docente } \\
\text { y no el estudiante quien dice } \\
\text { qué actividad se va a hacer }\end{array}$ & - & 25 & 69 & 6 & - \\
\hline 4 & $\begin{array}{l}\text { Mi principal rol como } \\
\text { docente es posibilitar el } \\
\text { desarrollo de la capacidad } \\
\text { investigativa en el estudiante }\end{array}$ & 22 & 75 & 3 & - & - \\
\hline 5 & $\begin{array}{l}\text { El profesir sabe más que el } \\
\text { estudiante y no debería permitir } \\
\text { que el estudiante intente } \\
\text { proporcionar una respuesta } \\
\text { a un interrogante, cuando él } \\
\text { puede explicarlo directamente }\end{array}$ & - & - & 31 & 69 & - \\
\hline 6 & $\begin{array}{l}\text { Los estudiantes aprenden } \\
\text { mejor cuando ellos } \\
\text { encuentran la solución a un } \\
\text { problema por sí mismos }\end{array}$ & 41 & 53 & - & 6 & - \\
\hline 7 & $\begin{array}{l}\text { Qué tanto los estudiantes } \\
\text { aprenden, depende de qué } \\
\text { tanto conocimiento previo } \\
\text { ellos tienen del tema }\end{array}$ & 3 & 41 & 55 & - & - \\
\hline 8 & $\begin{array}{l}\text { Debería permitírsele a los } \\
\text { estudiantes hallar la solución a } \\
\text { los problemas por sí mismos, } \\
\text { antes que el profesor les } \\
\text { indique cómo hacerlo }\end{array}$ & 19 & 78 & 3 & - & - \\
\hline
\end{tabular}


Carmelina Encarnación Mosquera

\begin{tabular}{|c|c|c|c|c|c|c|}
\hline & $\begin{array}{c}\text { Creencias que definen las } \\
\text { acciones }\end{array}$ & $\begin{array}{l}\text { Totalmente } \\
\text { de } \\
\text { acuerdo } \\
\%\end{array}$ & $\begin{array}{c}\text { De } \\
\text { acuerdo } \\
\%\end{array}$ & $\begin{array}{c}\text { En } \\
\text { desacuerdo } \\
\%\end{array}$ & $\begin{array}{l}\text { Totalmen- } \\
\text { te en } \\
\text { desacuerdo } \\
\% \%\end{array}$ & $\begin{array}{l}\text { No } \\
\text { responde } \\
\%\end{array}$ \\
\hline 9 & $\begin{array}{l}\text { Cuando se trata de alto } \\
\text { desempeño, me refiero a un } \\
\text { desempeño que supera el } \\
\text { nivel de logro esperado }\end{array}$ & 9 & 75 & 10 & - & 6 \\
\hline 10 & $\begin{array}{l}\text { Un salón en silencio es necesio } \\
\text { para un aprendizaje efectivo }\end{array}$ & - & 16 & 72 & 12 & - \\
\hline 11 & $\begin{array}{l}\text { Pensar y razonar es más } \\
\text { importante que un contenido } \\
\text { curricular específico }\end{array}$ & 19 & 75 & 6 & - & - \\
\hline 12 & $\begin{array}{l}\text { Qué y cómo se enseña este } \\
\text { determinado por lo que para } \\
\text { el docente significa enseñar }\end{array}$ & 16 & 34 & 47 & - & 3 \\
\hline 13 & $\begin{array}{l}\text { Cómo y qué se enseña debe } \\
\text { estar determinado por quién es } \\
\text { el estudiante y cómo aprende }\end{array}$ & 22 & 59 & 16 & - & 3 \\
\hline
\end{tabular}




\section{Annex 2. Description of classroom activities}

\begin{tabular}{|c|c|c|c|c|c|c|}
\hline $\mathbf{N}^{\circ}$ & Describiendo una clase en particular & $\underset{\%}{\text { Siempre }}$ & $\begin{array}{c}\text { Casi } \\
\text { siempre } \\
\%\end{array}$ & $\begin{array}{c}\mathrm{A} \\
\text { veces } \\
\%\end{array}$ & $\begin{array}{c}\text { Nunca } \\
\%\end{array}$ & $\begin{array}{l}\text { No } \\
\text { responde } \\
\%\end{array}$ \\
\hline 1 & Presento nuevos temas a la clase & 6 & 72 & 19 & & 3 \\
\hline 2 & Explico claramente los objetivos de aprendizaje & 25 & 59 & 13 & & 3 \\
\hline 3 & Reviso con los estudiantes las tareas asignadas & 34 & 50 & 13 & & 3 \\
\hline 4 & Promuevo el trabajo cooperativo & 34 & 47 & 16 & & 3 \\
\hline 5 & $\begin{array}{l}\text { Diseño actividades variadas para responder } \\
\text { a los diferentes niveles de los estudiantes }\end{array}$ & 20 & 47 & 33 & & \\
\hline 6 & $\begin{array}{l}\text { Propicio la participación de los estudiantes } \\
\text { en la propuesta de temas y actividades }\end{array}$ & 16 & 34 & 47 & & 3 \\
\hline 7 & $\begin{array}{l}\text { Al comienzo de la clase hago un breve } \\
\text { repaso del tema de la clase anterior }\end{array}$ & 16 & 53 & 28 & & 3 \\
\hline 8 & $\begin{array}{l}\text { Monitoreo el trabajo que los estudiantes } \\
\text { realizan durante la clase }\end{array}$ & 69 & 28 & & & 3 \\
\hline 9 & $\begin{array}{l}\text { Realizo trabajo personalizado } \\
\text { con los estudiantes }\end{array}$ & 3 & 25 & 69 & & 3 \\
\hline 10 & $\begin{array}{l}\text { Los estudiantes evalúan y reflexionan } \\
\text { su proceso de aprendizaje }\end{array}$ & 12 & 41 & 41 & 3 & 3 \\
\hline 11 & $\begin{array}{l}\text { Uso estrategias para revisar la } \\
\text { comprensión de las instrucciones }\end{array}$ & 9 & 63 & 25 & & 3 \\
\hline 12 & $\begin{array}{l}\text { Uso estrategias para revisar la } \\
\text { comprensión del tema }\end{array}$ & 31 & 53 & 13 & & 3 \\
\hline 13 & $\begin{array}{l}\text { Realizo actividades que integren } \\
\text { todas las habilidades lingüísticas }\end{array}$ & 19 & 47 & 31 & & 3 \\
\hline 14 & $\begin{array}{l}\text { Los estudiantes realizan actividades por fuera } \\
\text { de la clase para reforzar su aprendizaje }\end{array}$ & 16 & 29 & 52 & & 3 \\
\hline 15 & $\begin{array}{l}\text { Administro exámenes para evaluar } \\
\text { el aprendizaje de los estudiantes }\end{array}$ & 25 & 50 & 22 & & 3 \\
\hline 16 & Implemento diferentes patrones de interacción & 6 & 47 & 41 & & 6 \\
\hline 17 & $\begin{array}{l}\text { Doy feedback a los estudiantes } \\
\text { a partir de su desempeño }\end{array}$ & 2 & 56 & 16 & & 3 \\
\hline 18 & $\begin{array}{l}\text { Promuevo actividades que varíen la } \\
\text { agrupación de los estudiantes }\end{array}$ & 9 & 44 & 41 & 3 & 3 \\
\hline 19 & $\begin{array}{l}\text { El objetivo de aprendizaje se centra } \\
\text { en lo que el estudiante es capaz de } \\
\text { hacer con el tema aprendido }\end{array}$ & 3 & 72 & 22 & & 3 \\
\hline
\end{tabular}


Carmelina Encarnación Mosquera

\begin{tabular}{|c|l|c|c|c|c|c|}
\hline $\mathbf{N}^{\mathbf{2}}$ & \multicolumn{1}{|c|}{ Describiendo una clase en particular } & $\begin{array}{c}\text { Siempre } \\
\%\end{array}$ & $\begin{array}{c}\text { Casi } \\
\text { siempre } \\
\%\end{array}$ & $\begin{array}{c}\text { A } \\
\text { veces } \\
\%\end{array}$ & $\begin{array}{c}\text { Nunca } \\
\%\end{array}$ & $\begin{array}{c}\text { No } \\
\text { responde } \\
\%\end{array}$ \\
\hline 20 & El enfoque de mi clase es basado en tareas & 38 & 56 & 3 & 3 \\
\hline 21 & $\begin{array}{l}\text { Mi clase se basa en presentación, } \\
\text { práctica y producción }\end{array}$ & 13 & 28 & 56 & 3 \\
\hline 22 & Mi clase se basa en el enfoque por proyectos & 3 & 16 & 56 & 22 & 3 \\
\hline 23 & Mi clase se basa en matemáticas & & 31 & 60 & 6 & 3 \\
\hline 24 & Mi clase se basa en contenido y lengua & 6 & 28 & 57 & 6 & 3 \\
\hline
\end{tabular}

